\title{
Synchrotron based study of As mobility and speciation in tailings from a mining site in Mexico
}

Loredo-Portales R. ${ }^{1,3}$, Castillo-Michel H. ${ }^{2}$, Aquilanti G. ${ }^{3}$, De La Rosa-Álvarez Ma. G. ${ }^{4}$, RochaAmador D. O. ${ }^{1}$ Vogel-Mikus K. ${ }^{5,6}$, Kump P. ${ }^{6}$ and Cruz-Jiménez G. ${ }^{1 *}$

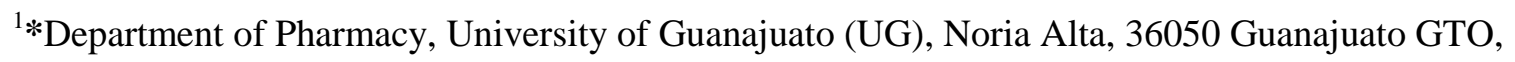
Mexico

${ }^{2}$ ID 21, European Synchrotron Radiation Facility, 6 Jules Horowitz, 38000 Grenoble, France ${ }^{3}$ Elettra-Sincrotrone Trieste, Strada Statale 14, km 163.5, 34149 Area Science Park, Basovizza, Italy ${ }^{4}$ Department of Engineering, University of Guanajuato, 103 Lomas Del Bosque, 37150 León, GTO, Mexico

${ }^{5}$ Department of Biology, University of Ljubljana, 101 Jamnikarjeva, 1000, Ljubljana, Slovenia

${ }^{6}$ Jožef Stefan Institute, Jamova39, SI-1000, Ljubljana, Slovenia

*Corresponding author

\begin{abstract}
Mine Tailings of "La Aurora", a mining site located in central Mexico, display anomalous concentrations of $\mathrm{As}, \mathrm{Zn}, \mathrm{Pb}, \mathrm{Cu}$ and $\mathrm{Cd}$. However, data on their potential toxicity is not available. It is known that toxicity is related to elemental speciation. In this work, we evaluated the biogeochemical dynamics of As in terms of mobility and chemical nature. For this purpose, samples of soils, mine tailings, plants and water were collected. Synchrotron based techniques and chemical fractionation extractions were used to determine As speciation, potential mobility, and bioavailability. Our results showed that As is present in concentrations up to 12,672 \pm 34 and $326 \pm$ $10 \mathrm{mg} \cdot \mathrm{kg}^{-1}$ in mine tailings and nearby soils, respectively. X-ray Absorption Spectroscopy (XAS) analysis demonstrated that $\mathrm{As}$ is present as $\mathrm{As}^{\mathrm{V}}$ in a structure similar to that of kankite $\left(\mathrm{FeAsO}_{4} \cdot 3.5 \mathrm{H}_{2} \mathrm{O}\right)$ and beudantite $\left(\mathrm{PbFe}_{3}\left(\mathrm{AsO}_{4}\right)\left(\mathrm{SO}_{4}\right)(\mathrm{OH})_{6}\right)$. The presence of these mineral structures were confirmed by $\mu$ X-Ray Fluorescence and X-ray Absorption Near Edge Structure ( $\mu$ $\mathrm{XRF}$ / XANES). Arsenic was also detected in plant species growing in the tested soils. The highest As concentrations were determined in the roots of Baccharis salicifolia (up to $44 \mathrm{mg} \cdot \mathrm{kg}^{-1}$ ). In a creek nearby the mine tailings, As levels of $163 \pm 15 \mu \mathrm{g} \cdot \mathrm{L}^{-1}$ were quantified. In terms of
\end{abstract}


phytoaccessibility and bioaccessibility, As levels can be considered toxic for both plants and humans. According to sequential extraction results, As is associated mainly with the crystalline FeOx fraction.

Keywords: Arsenic, XAS, Tailing, Soil, Phytoaccessibility, Bioaccessibility

\section{Introduction}

The Tailings of "La Aurora", a mining site located 4 km NW of Xichú (Guanajuato, Mexico), are part of a natural protected area denominated the Sierra Gorda Biosphere Reserve. This zone is recognized for its high biodiversity, biological resources, and the existence of some endangered species [1]. This mining site was mainly exploited for $\mathrm{Au}, \mathrm{Ag}, \mathrm{Pb}, \mathrm{Zn}$ and $\mathrm{Cu}$ until 1957 [2]. References indicated that "La Aurora" contain about one million tons of mine waste material, and that ore material contains up to $62,000,2,400,13,000$ and $17,000 \mathrm{mg} \cdot \mathrm{kg}^{-1}$ of $\mathrm{As}, \mathrm{Cu}, \mathrm{Zn}$, and $\mathrm{Pb}$, respectively. Ore mineral is formed by chalcopyrite, galena, sphalerite, and other minerals containing $\mathrm{Ag}, \mathrm{Au}$, and As. Other minerals recently identified comprise pyrite, gypsum, and cuprite $[3,4]$. Processes like leaching and bioaccumulation highly contribute to the contamination with these elements of a nearby creek and the vegetation established at the site [5].

Arsenic toxicity is well known and this element has been classified as a human carcinogen [6]. The alert has arisen because water from creeks near this site is used for the irrigation of crops and vegetation is used as food for livestock by the local community. Thus, Arsenic mobilization from these mine tailings comprises an environmental and human health threat. Arsenic has a complicated chemistry due to its tendency to exist simultaneously in multiple oxidation states and phases [7]. Arsenic occurs in association with deposits of $\mathrm{Pb}, \mathrm{Ag}$ and $\mathrm{Zn}$. The most common As minerals found in mine tailings are arsenopyrite (FeAsS) and its derived oxidation products including scorodite $\left(\mathrm{FeAsO}_{4} \cdot 2 \mathrm{H}_{2} \mathrm{O}\right)$. Environmental weathering processes mobilize As from tailings exposed to air and rain, forming $\mathrm{As}^{\mathrm{III}}$ and $\mathrm{As}^{\mathrm{V}}$ species, which could reach groundwater or surrounding soils and be coprecipitated or sorbed into secondary minerals $[8,9]$.

In order to properly assess the environmental and human health risk, data on As speciation, mobility, and accessibility is needed. Definition of the terms bioaccessibility and bioavailability continues to be a topic of discussion [10]. Bioavailability is the fraction of the element that is found available to be absorbed by a living organism. This is directly related to its solubility in the soil solution and can be measured by using chemical extractants [11-14]. Bioaccessibility refers to the soluble fraction in the gastrointestinal environment; thus, it is the fraction that is suitable for 
absorption. To determine this fraction, simulated physiological extraction of the elements is used $[15,16]$. Phytoaccessibility is the available fraction for absorption by plants, and a battery of organic acids is employed for the extraction [17 and 18]. These parameters depend on various factors, such as $\mathrm{pH}$, redox potential, speciation, and the presence of different minerals, among others. Chemical fractionation through a Sequential Extraction Procedure (SEP) comprises another tool to assess the mobility of Potential Toxic Elements (PTE). SEP is used to estimate the fractions of PTE according to its solubility, employing solutions that produce changes in cationic composition, redox conditions, organic matter degradation, and chemicals strong enough to produce the solubilization of resistant minerals or elements trapped into secondary minerals. This information provides an idea about short and long term availability and chemical forms of the elements $[19,20]$.

Several techniques are used to quantify and study $\mathrm{As}^{\mathrm{III}}$ and $\mathrm{As}^{\mathrm{V}}$ species in water and soil solutions, such as Hydride Generation-Atomic Absorption Spectroscopy (HG-AAS) and High Performance Liquid Chromatography (HPLC). In recent decades, synchrotron techniques have demonstrated their utility in environmental science for studying metal(loid)s geochemical processes in complex matrices such as polluted soils and mine tailings, and their uptake and metabolism in living organisms (e.g. plants). The most commonly used techniques includes XAS to determine speciation and chemical coordination, and $\mu-\mathrm{XRF} / \mathrm{XANES}$ for mapping the distribution of elements and insitu speciation. XAS constitutes a direct technique not requiring chemical extraction pre-treatments, it is nondestructive, and allows saving the sample for other analyses [21, 22]. In this work, a combination of traditional wet chemistry methods and synchrotron techniques (XAS and $\mu-\mathrm{XRF} /$ XANES) were used to better understand As speciation, mobilization and related health risks in the region of the "La Aurora" mining site.

\section{Methods and Materials}

\subsection{Sample collection and preparation}

Samples of tailings, soils, plants and water were collected at "La Aurora" (Fig. 1). A total of 10 sampling points were distributed over the mining site. At each point, composite samples were collected at depths of 0.01 and $0.3 \mathrm{~m}$, except in soils where all samples are composites collected at $0.3 \mathrm{~m}$ in depth. Soil samples were stored in plastic bags at room temperature. Water samples were collected at three points in a nearby creek: before; during, and after the mine tailings with respect to water flow. Samples were added with $\mathrm{HNO}_{3}(0.05 \% \mathrm{v} / \mathrm{v})$ and stored in polypropylene bottles at $4{ }^{\circ} \mathrm{C}$ until analysis. Three specimens of six plant species growing in the soils sampling zone were 
collected and stored in plastic bags. All samples were transferred to the Laboratory for Toxicity and Environmental Risk Assessment located at the University of Guanajuato, Mexico.

Soil and tailings were dried at $50^{\circ} \mathrm{C}$ for $24 \mathrm{~h}$ and mixed using the "coning and quartering" method [23]. Later, the samples were sieved and separated into two particle sizes: $<0.25$ and $<0.85 \mathrm{~mm}$ respectively according to NOM-147-SEMARNAT/SSA1-2004 (Mexico), and U.S. EPA method 3050b for soil analysis [24 and 25]. In addition, water samples were filtered with a $2.5 \mu \mathrm{m}$ membrane. Plant samples (See Table 3) were washed with deionized water and a solution of $\mathrm{HNO}_{3}$ $(0.05 \% \mathrm{v} / \mathrm{v})$. Specimens were divided into roots, stems, and leaves, dried at $50^{\circ} \mathrm{C}$, pulverized, sieved to a $0.85-\mathrm{mm}$ particle size, and stored in centrifuge tubes. Not all plant roots were recovered completely, because of the soil composition and high complexity of the root system.

\subsection{Arsenic content analysis}

Mine tailings and soils were analyzed by HG-AAS, and water samples by Graphite Furnace Atomic Absorption (GF-AAS). Tailings and soil samples were digested according the 3050b EPA method [25] as follows: $0.5 \mathrm{~g}$ of sample were weighed in triplicate. Later, $5 \mathrm{~mL}$ of $\mathrm{HNO}_{3}$ were added to the solutions and boiled for about $1 \mathrm{~h}$ in reflux. Then, $3 \mathrm{~mL}$ of $\mathrm{H}_{2} \mathrm{O}_{2}(30 \%)$ were added and boiled under the same conditions for $1 \mathrm{~h}$. Finally, the solutions were centrifuged at $3,000 \times \mathrm{g}$, the supernatant was filtered through a $2.5 \mu \mathrm{m}$ membrane, gauged at $10 \mathrm{~mL}$, and stored at $4^{\circ} \mathrm{C}$ in centrifuge tubes until analysis. Hydride generation was carried out utilizing KI as reduction agent and $\mathrm{NaBH}_{4}$, to produce As hydrides. For these analyses, a Perkin Elmer HGA 800 spectrometer with an As cathode lamp at $18 \mathrm{~mA}$ current and a $0.7 \mathrm{~mm}$ slit, using a $\lambda$ of $193.7 \mathrm{~nm}$ and an integration time of $0.35 \mathrm{sec}$, were employed. Water samples were centrifuged at 3,000 $\times \mathrm{g}$, and solutions were filtered through a $2.5 \mu \mathrm{m}$ membrane, and analyzed by GF-AAS by triplicate utilizing a SpectrAA 220z at a $\lambda 193.7 \mathrm{~nm}$ with a Zeeman As ultra-lamp at $10 \mathrm{~mA}$ current.

\subsection{Extraction procedures}

Arsenic bioaccessibility was determined in soils and tailings by performing an extraction in gastric simulated media, according to the Mexican regulation [24]. In summary, $1 \pm 0.05 \mathrm{~g}$ of sample in triplicate $(<250 \mathrm{~mm}$ particle size) were weighed in a glass vessel; then, $100 \pm 0.5 \mathrm{~mL}$ of glycine (0.4M; pH 1.5) were added. The solutions were stirred at $30 \pm \mathrm{rpm}$ and $37 \pm 2{ }^{\circ} \mathrm{C}$ for about $1 \mathrm{~h}$. Twenty $\mathrm{mL}$ of the gastric extraction was filtered with a $2.5 \mu \mathrm{m}$ membrane and stored at $4^{\circ} \mathrm{C}$ until analysis. With the data obtained from the bioaccessibility extractions, the As estimated Dose for oral Exposure (Exposure Dose [ED]) in children was calculated in order to establish the potential 
toxicity via soil ingestion. The ED was calculated according the equation 2.1 based on previous studies in the same region [26].

$E D=\frac{T C * I R * U C F}{B W}(E F)(B F)$

Where ED is the exposure dose (mg. $\mathrm{kg} \cdot \mathrm{day}^{-1}$ of As), TC is the total content of As in soil $\left(\mathrm{mg} \cdot \mathrm{kg}^{-1}\right)$, IR is the ingestion rate per day $\left(200 \mathrm{mg} \cdot \mathrm{day}^{-1}\right), \mathrm{UCF}$ is the units correction factor $\left(1 \mathrm{x} 10-6 \mathrm{~kg} \cdot \mathrm{mg}^{-1}\right)$, BW is the body weight for a child aged between 6 and 9 years $(25 \mathrm{~kg})$, EF is the exposure fraction of hours per week and BF is the bioaccesible fraction of As.

Arsenic phytoaccessibility was determined by extracting the samples with a solution of Low Molecular Weight Organic Acids (LMWOA) that are commonly present in the rhizospheric environment. For this extraction, $<0.85$ and $<0.25 \mathrm{~mm}$ particle size samples were utilized. The extraction solution was prepared according to Cieśliński et al. [27] (See Table 1). Extractions were performed as follows: $1 \mathrm{~g}$ of sample by triplicate was weighed in a $50 \mathrm{~mL}$ centrifuge tube; then, 15 $\mathrm{mL}$ of LMWOA were added, the $\mathrm{pH}$ was adjusted to $4 \pm 0.1$, and the solutions were shaken for $5 \mathrm{~h}$. Finally, samples were centrifuged at 3,000 $\times \mathrm{g}$, filtered through a $2.5 \mu \mathrm{m}$ membrane, and stored at $4^{\circ} \mathrm{C}$ until analysis. Bioaccumulation (BF) and Translocation Factors (TF) were calculated based on the equations 2.2 and 2.3 [28].

$B F=\frac{T c}{S c}$

Where $\mathrm{BF}$ is the bioaccumulation factor, $\mathrm{Tc}$ is the As content in plant tissues (root, steam or leave) and Sc is the As content in soil.

$T F=\frac{A T c}{R c}$

Where TF is the Translocation Factor, ATc is the As content in aerial tissues (steam or leaves) and $\mathrm{Rc}$ is the As content in root tissue.

Arsenic fractionation through SEP was performed to distinguish between As labile and non-labile fractions using a set of chemical solutions with increasing dissolution strength. SEP was performed following the methodology described by Wenzel et al. [29], as follows: using $1 \mathrm{~g}$ of sample $(<0.85$ and $<0.25 \mathrm{~mm}$ particle size), SEP was performed in five steps: 1) exchangeable fraction, $25 \mathrm{~mL}$ of $\left(\mathrm{NH}_{4}\right)_{2} \mathrm{SO}_{4}(50 \mathrm{mM})$ were added and the solution was shaken during $4 \mathrm{~h}$ at $\left.25^{\circ} \mathrm{C} ; 2\right)$ specifically 
adsorbed fraction, $25 \mathrm{~mL}$ of $\left(\mathrm{NH}_{4}\right) \mathrm{H}_{2} \mathrm{PO}_{4}(50 \mathrm{mM})$ were added to the residues from the previous step and the solution was shaken during $16 \mathrm{~h}$ at $25^{\circ} \mathrm{C}$; 3) bound to amorphous Fe oxide fraction, 25 $\mathrm{mL}$ of $\left(\mathrm{NH}_{4}\right)_{2} \mathrm{C}_{2} \mathrm{O}_{4} / \mathrm{H}_{2} \mathrm{C}_{2} \mathrm{O}_{4}$ buffer $(200 \mathrm{mM}$; $\mathrm{pH}$ adjusted to $3.25 \mathrm{pH})$ were added to the residues from the previous step and the solution was shaken during $4 \mathrm{~h}$ at $25^{\circ} \mathrm{C}$; 4) the crystalline $\mathrm{Fe}$ oxidebound fraction, $25 \mathrm{~mL}$ of $\left(\mathrm{NH}_{4}\right)_{2} \mathrm{C}_{2} \mathrm{O}_{4} / \mathrm{H}_{2} \mathrm{C}_{2} \mathrm{O}_{4}$ buffer and $\mathrm{C}_{6} \mathrm{H}_{8} \mathrm{O}_{6}(200 ; 100 \mathrm{mM}, 3.25 \mathrm{pH})$ were added to the residues from the previous step, and the solution was heated at $96 \pm 3^{\circ} \mathrm{C}$ and shaken during $30 \mathrm{~min}$, 5) residual fraction, acid digestion as previously described in section 2.2 was performed in the residues from the previous step.

After each step, the supernatant extraction solutions recovered were centrifuged at 3,000 $\times \mathrm{g}$ and filtered through a $2.5 \mu \mathrm{m}$ membrane. Final solutions were stored at $4^{\circ} \mathrm{C}$ until analysis. Solid residues were washed three times with $10 \mathrm{~mL}$ of $\mathrm{NaCl}(0.5 \mathrm{M})$ before starting a new step.

\subsection{Bulk XAS experiments}

XAS analyses were performed at the XAFS Beamline of Elettra Sincrotrone Trieste [30]; Elettra was operated with a ring energy of $2 \mathrm{GeV}$ and a current of $310 \mathrm{~mA}$. For these experiments, samples of tailings and soils of $<0.25$ and $<0.85 \mathrm{~mm}$ particle sizes were used. Due to limited access to synchrotron beam time, only some representative samples were measured. All samples were homogenized using an agate mortar, mixed with boron nitride or polyvinyl pyrrolidone, and prepared as pellets. Model compounds were mounted in-between Kapton ${ }^{\circledR}$ tape or were prepared as pellets according to its suitable absorption length. Samples were compared against a set of mineral compounds commonly present in mine tailings; some of these minerals were obtained from Excalibur minerals and its chemical composition and structure were confirmed by $\mu$-XRF and EXAFS. Arsenic co-precipitated with ferrihydrite was synthesized at our laboratory according to Niazi et al. [31]. We employed the following standard compounds: kankite $\left(\mathrm{FeAsO}_{4} \cdot 3.5 \mathrm{H}_{2} \mathrm{O}\right) ; \mathrm{As}^{\mathrm{V}}$ co-precipitated with ferrihydrite (As-Fh); beudantite $\left(\mathrm{PbFe}_{3}\left(\mathrm{AsO}_{4}\right)\left(\mathrm{SO}_{4}\right)(\mathrm{OH})_{6}\right)$; bukovskyite $\left(\mathrm{Fe}_{2}\right.$ $\left.\left(\mathrm{AsO}_{4}\right)\left(\mathrm{SO}_{4}\right)(\mathrm{OH}) \cdot 7 \mathrm{H}_{2} \mathrm{O}\right)$; adamite $\left(\mathrm{Zn}_{2} \mathrm{AsO}_{4} \mathrm{OH}\right)$; arsenolite $\left(\mathrm{As}_{2} \mathrm{O}_{3}\right)$; arsenocysteine (AsCys); austinite $\left(\mathrm{CaZnAsO}_{4}(\mathrm{OH})\right)$; clinoclase $\left(\mathrm{Cu}_{3} \mathrm{AsO}_{4}(\mathrm{OH})_{3}\right)$; olivenite $\left(\mathrm{Cu}_{2} \mathrm{AsO}_{4}(\mathrm{OH})\right)$; arseniosiderite $\left(\mathrm{Ca}_{2} \mathrm{Fe}_{3} \mathrm{O}_{2}\left(\mathrm{AsO}_{4}\right)_{3} \mathrm{O}_{2} \cdot 3 \mathrm{H}_{2} \mathrm{O}\right)$; pharmacosiderite $\left(\mathrm{KFe}_{4}\left(\mathrm{AsO}_{4}\right)_{3}(\mathrm{OH})_{4} \cdot(6-7) \mathrm{H}_{2} \mathrm{O}\right)$; sodium arsenate $\left(\mathrm{NaH}_{2} \mathrm{AsO}_{4} \cdot \mathrm{H}_{2} \mathrm{O}\right)$, and scorodite $\left(\mathrm{FeAsO}_{4} \cdot 2 \mathrm{H}_{2} \mathrm{O}\right)$.

XAS data acquisition was performed in fluorescence mode using a Silicon Drift Detector for diluted samples (soils), and in transmission mode for mineral samples, standard compounds, and samples with high As concentration. The As K-edge (11,867 eV) was scanned $100 \mathrm{eV}$ below the edge and $800 \mathrm{eV}$ above the edge to acquire XANES and Extended X-ray Absorption Fine-Structure (EXAFS) 
information from each sample. We collected multiple scans (2-10) based on spectral quality and merged into a final spectrum. XANES and EXAFS data analysis were performed using Athena and Artemis software respectively [32] based on the IFEFFIT XAFS analysis library. The spectrum of Gallium Arsenide (GaAs) was collected in each measure as a standard to align the energy scale. Normalized data were employed for Linear Combination Analysis (LCA). LCA were accomplished within the $-20<\mathrm{Eo}>30 \mathrm{eV}$ range, using all possible combinations of standards (4-5 variables), all weights between $0-1$, but not forced to sum 1 for better alignment (weights were recalculated), all spectra shared the same value of $\mathrm{E}_{0}$.

\section{4. $\mu-X R F$ and $\mu$-XANES experiments}

Maps of $\mu$-XRF and micro-XANES ( $\mu$-XANES) spectra were collected on the Environmental and Material Science MicroXAS Beamline at the Advanced Light Source (ALS) at Berkeley. The ALS operated with a beam energy of $1.9 \mathrm{GeV}$ and a ring current of $500 \mathrm{~mA}$ in multi-bunch mode. The MicroXAS beam uses a bending magnet to generate radiation, utilizes a two-crystal monochromator of Si (111), and employs a seven-element Ge solid-state fluorescence detector (Canberra; $50 \mathrm{~mm} 2$ per element) [33].

Maps of $\mu$-XRF were performed in a tailing sample with a $<0.85-\mathrm{mm}$ particle size, embedded in epoxy resin, polished to a $20 \mu \mathrm{m}$ thickness, and detached from the glass substrate for analysis. Maps were collected at $12.1 \mathrm{keV}$ with $30 \mathrm{msec}$ of dwell time, using a $4 \times 4-\mu \mathrm{m}(\mathrm{V} \times \mathrm{H})$ beam and pixel size. Fluorescence yield was normalized by $\mathrm{I}_{0}$ and dwell time. For $\mu$-XAFS, data acquisition was collected from 11,767 to $12,478 \mathrm{eV}$.

\section{Results and Discussion}

\subsection{Arsenic Content Analysis}

Some samples were analyzed by three techniques for validation purposes; GH-AAS, XRF [34] and inductively coupled plasma optical emission spectrometry (ICP-OES). Results indicated that XRF and ICP-OES data are alike and statistically different from GH-AAS ( $\mathrm{p}<0.05)$. However, GH-AAS data showed better recovery percentage $95.32 \%$ against ICP-OES and XRF (139\% and 83\%., respectively). As content in mine tailings and soil samples ranged, between 3,139 \pm 300 to 12,672 \pm 34 , and $181 \pm 17$ to $719 \pm 13 \mathrm{mg} \cdot \mathrm{kg}^{-1}$, respectively, with no significant differences in As content between particle sizes $(p<0.05)$ (See Table 2.). Arsenic content in tailings and soils from this zone is higher than the values allowed in the Mexican regulation for agricultural, commercial or residential, and industrial use (22 and $260 \mathrm{mg} \cdot \mathrm{kg}^{-1}$; [24]). The concentrations of As detected in this work are similar with those of presented in previous reports from other mining sites in Mexico. For 
example, in a valley in the city of Zimapán, Hidalgo, Mexico As content ranged from 4 to 14,700 $\mathrm{mg} \cdot \mathrm{kg}^{-1}$; this is a region located at a highly exploited mining site for $\mathrm{Pb}, \mathrm{Zn}$, and $\mathrm{Ag}$ since the year of 1576 [35]. The Villa de la Paz Matehuala is a mining site where As content has been detected in concentrations from 15 to $7,200 \mathrm{mg} \cdot \mathrm{kg}^{-1}$. This place has been exploited for $\mathrm{Pb}, \mathrm{Zn}$, and $\mathrm{Ag}$, for more than 200 years [36]. Arsenic content in soils and plants near the mine tailings $(100 \mathrm{~m})$ was lower, which suggests a natural attenuation. In mine impacted sites some processes like adsorption to the mineral water interface, mineral precipitation, among others can reduce the mass mobility [37]. However, As soil content remains in a concentration sufficient to surpass the regulation for soil content and plant toxicity [24, 38, and 39].

Water samples from a creek near the mine tailings zone, displayed As concentrations ranging from $128 \pm 8$ to $163 \pm 15 \mu \mathrm{g} \cdot \mathrm{L}^{-1}$. The highest As concentrations were found at sampling points after the mine tailing zone in terms of river flow. The maximum allowed As content in water for human consumption has been established at $10 \mu \mathrm{g} \cdot \mathrm{L}^{-1}$ [40], As concentration in water samples from the creek surpassed this limit. It is noteworthy that the main source of water in this region comprises creeks and groundwater, and that at no more than $100 \mathrm{~m}$ from the tailings, some active corn fields utilize this water for irrigation.

\subsection{Arsenic Phytoaccessibility}

The phytoaccessible As fraction was determined in some representative samples of tailings and soils with particle sizes of $<0.25$ and $<0.85 \mathrm{~mm}$. Phytoaccessible As in mine tailings and soils ranged between $211 \pm 11$ to $714 \pm 77$ and $43 \pm 10$ to $116 \pm 32 \mathrm{mg} \cdot \mathrm{kg}^{-1}$, respectively, with no significant differences in As concentration between the samples of different particle size $(p<0.05)$ (See Table 2). These values are useful for measuring the fraction of As that is potentially available for plant uptake and consequently useful for determining their potential toxicity. Arsenic has been shown toxic to the plants in a range between 40 and $200 \mathrm{mg} \cdot \mathrm{kg}^{-1}$ in sandy and clay soils, and between 0.5 and $1 \mathrm{mg} \cdot \mathrm{L}^{-1}$ in hydroponic experiments [38, 39]. Some plant species growing around mine tailings, shrubs in majority, were analyzed for As; however, no elevated As concentrations were found in their tissues, with exception of the species Fouquieria splendens, Cineraria marítima and Baccharis salcifolia, which exhibited the highest As concentration in root and stem tissues (44 \pm 6 and $30 \pm 4 \mathrm{mg} \cdot \mathrm{kg}^{-1}$, respectively). BF and TF were also calculated for plants with As content in its tissues with values over the $\mathrm{LD}$, with results falling, respectively, within the range of 0.23 to 0.38 and 0.14 to 0.61 (See Table 3). These are low values for species that are considered as a hyperaccumulator according the literature; e.g. BF and TF for As hyperaccumulators, Pteris vittata and Pteris cretica range of up to 7.34 and 3.98, respectively. The As concentration in plant dry 
tissues, in order to be classified as an As hyperaccumulator is $\geq 1,000 \mathrm{mg} \cdot \mathrm{kg}^{-1}$ [41 and 42]. Phytoaccessible As in mine tailings and soils is between 6 and $7 \%$ and 16 and 24\%, respectively against the total As soil content. This could explain the relatively low As concentration in plant tissues, and it is important to note that the plants growing at the mining site did not show any physical signs of toxicity.

\subsection{Bioaccessibility}

Bioaccessible As was determined in some representative tailing and soil samples with a particle size of $<0.25 \mathrm{~mm}$, according to the Mexican regulation [24]. Bioaccessible As in mine tailings and soils ranged from $266 \pm 10$ to $689 \pm 16 \mathrm{mg} \cdot \mathrm{kg}^{-1}$ and from $67 \pm 10$ to $77 \pm 13 \mathrm{mg} \cdot \mathrm{kg}^{-1}$, respectively (See Table 2). The bioaccessible As values were employed for the evaluation of ED for child population. Results showed that As content in the mine tailings surpass the ED limit for chronic exposure $(3 \times$ $10^{-4} \mathrm{mg} \cdot \mathrm{kg}^{- \text {day }^{-1}}$ ), which involves hyperpigmentation, keratosis, and possible vascular complications [6]. ED in mine tailings and soils ranged, from $4 \times 10^{-4}$ to $10 \times 10^{-4}$ and $0.9 \times 10^{-4}$ to $2.7 \times 10^{-4} \mathrm{mg} / \mathrm{kg}^{-}$day $^{-1}$. Even higher ED have been reported in polluted sites in México like in Villa de la Paz, San Luis Potosi, Mexico [43]. Bioaccessible As ranged from 526 to $885 \mathrm{mg} \cdot \mathrm{kg}^{-1}$ in soils from this mining area, and the ED ranged from $6.3 \times 10^{-4}$ to $1.57 \times 10^{-3} \mathrm{mg} \cdot \mathrm{kg}$-day ${ }^{-1}$. Bioaccessible As in the tailings and soils from the "La Aurora" mining site represents around 5 to 8 and 24 to 37 $\%$, respectively, of the total As content. Similarly, to phytoaccessible As, the bioaccessible As concentration determined by simulated gastric media is sufficient to negatively affect human health under chronic exposure scenarios.

\subsection{SEP Experiments}

Results suggests that As in the mine tailing and soils is mainly associated to the crystalline $\mathrm{Fe}-\mathrm{Ox}$ with no significant difference between particle sizes $(p<0.05)$ with As concentrations of $1,317 \pm$ 290 to $5,233 \pm 441$ and $80 \pm 23$ to $236 \pm 53 \mathrm{mg} \cdot \mathrm{kg}^{-1}$, respectively (See Table 4). The general trend of SEP fractions was toward crystalline $\mathrm{Fe}-\mathrm{Ox}>$ residual > exchangeable > amorphous $\mathrm{Fe}-\mathrm{Ox}>$ adsorbed specifically, in mine tailings, and toward crystalline $\mathrm{Fe}-\mathrm{Ox}>$ residual $>$ exchangeable $>$ adsorbed $>$ amorphous Fe-Ox, in soils. According to the literature, As is usually adsorbed into $\mathrm{Fe}$ and Mn oxyhydroxides, clays, carbonates, and organic matter, and its adsorption of As into Fe, Al, and $\mathrm{Mn}-\mathrm{Ox}$ is critical for controlling its mobility. In addition, crystalline Fe-Ox exhibits 5-times lower solubility than amorphous Fe-Ox [35 and 44]. These results are in agreement with the low bio- and phytoaccessible As obtained in mine tailings and soils. 


\subsection{Bulk XAS Experiments}

XANES spectra and the EXAFS signal were collected for some representative tailing and soil samples (particle sizes, $<0.25$ and $<0.85 \mathrm{~mm}$ ). The results demonstrated that all samples share similar features with the iron arsenates kankite and beudantite (See Fig. 2). The presence of similar XANES features in tailings and soils could comprise evidence of mobilization into the soils. Bulk XANES spectra were compared with some mineral standards, and LCA were performed on all measured samples using Athena software [32]; the results are depicted in Table 5. LCA showed that As is mainly present as a secondary arsenate mineral with similar structure to kankite, and secondly, as a secondary lead-arsenate mineral beudantite. Other signals present in LCA included bukovskyite and clinoclase. The weight of these components in tailings and soils followed this trend: kankite > beudantite > bukovskyite > clinoclase, and kankite > bukovskyite > beudantite > clinoclase, respectively, with the exception of soil sample composite with particle size $<0.85 \mathrm{~mm}$ were only bukovskyite contribution was observed. In summary, As is present in secondary minerals such as kankite and is also linked with $\mathrm{Pb}$ and $\mathrm{Cu}$ minerals to a lesser extent. Kankite is a more hydrated form of scorodite and is formed in moderately acid $\mathrm{pH}$ conditions and sites with dry microclimates, but with damping during several months of the year [45]. Kankite is considered a rare mineral, but has been found as a common mineral in strongly weathered historical mine wastes. It is less stable than scorodite [46]. On the other hand beudantite is considered a typical mineral and acts as a natural sink for $\mathrm{Pb}$ and $\mathrm{As} \mathrm{[47].} \mathrm{In} \mathrm{"La} \mathrm{Aurora",} \mathrm{the} \mathrm{presence} \mathrm{of} \mathrm{these} \mathrm{hydrated} \mathrm{minerals} \mathrm{such} \mathrm{as}$ kankite can be explained because the site is hydrated by a near creek and vessels through mine tailing constantly.

Bulk XANES spectra were recorded in residues from previously described SEP. For this purpose, residues after SEP steps 2, 3, and 4 were utilized and labeled as follows: A) containing As associated to amorphous and crystalline Fe-Ox, and residual As fractions; B) containing As associated to crystalline $\mathrm{Fe}-\mathrm{Ox} \mathrm{As}$, and residual As fractions, and C) containing only the residual As fraction. XANES spectra performed in these residues (See Fig. 3). The results demonstrated that spectral features in all residues did not significantly change in comparison with those of the original spectra. This comprises evidence of the resistance of arsenate species to weathering, even to strong chemical attack, as in step 4 of SEP. The signal of arsenates such as kankite is observed persistently.

\subsection{Arsenic EXAFS and $\mu$-XAS Analysis}


EXAFS fits were applied in the kankite mineral standard and in one mine tailing and soil composites samples taken at $0.3 \mathrm{~m}$ depth with particle size of $<0.25 \mathrm{~mm}$. For this analysis, nonstructural parameters $\mathrm{S}_{0}{ }^{2}$ corresponding to overall damping of the EXAFS signal were set at the fixed value of 0.85 . $\mathrm{E}_{0}$ values were utilized as free parameters and were constrained to the same value for the same pairs of atoms, i.e., $\mathrm{E}_{0}$-oxy for As-O scattering, and $\mathrm{E}_{0}-\mathrm{Fe}$ for As-Fe scattering. Interatomic distances were left as free parameters. For $\sigma^{2}$ parameters associated with width-ofdistance distributions, the same parameters for the same pairs of atoms with similar interatomic distances were employed. Because the kankite crystal structure has not been well reported to date, we used scorodite crystal-structure information, which differs from that of kankite in terms of the hydration environment [48]. EXAFS analysis of As confirmed the structure of iron arsenate compounds such as kankite and scorodite, which share the tetrahedral $\mathrm{AsO}_{4}$ structure corresponding to a single scattering of 4 oxygen atoms in the first shell. Other signals were identified in the second shell, including 12 oxygen and $3 \mathrm{Fe}$ atoms. Refinement was performed in $\mathrm{R}$ space between 0.1 to $0.35 \mathrm{~nm}$ (See Table 6).

Maps of $\mu$-XRF were taken from a tailing sample of $0.01 \mathrm{~m}$ depth superficial sample, with particle size $<0.25 \mathrm{~mm}$ in two zones where the As- $\mathrm{Cu}-\mathrm{Fe}$ correlation was observed, and some $\mu$-XAS spectra were collected in order to obtain information on other mineral species (See Figs. 4 and 5). The results obtained have demonstrated that $\mu$-XANES features continue to be comparable with kankite and beudantite mineral standards. Specifically, in Fig. 4, spots 0 to 1 and 3 revealed more features similar to those of beudantite, while spots 2, 4 and 5 exhibited more features to those of kankite. In Fig. 5, spots 0 to 5, 11 and 12 revealed more features similar to those of beudantite, and spots 6 to 10 demonstrated features similar to those of kankite. These data corroborate the presence of iron arsenates similar in structure to kankite and beudantite in mine tailings. No features of copper arsenates were detected. However, in our companion study with these tailings at the $\mathrm{Cu} \mathrm{k}$ edge, some of the XANES spectra exhibited features related to those suggesting copper arsenates [49]. Since the $\mathrm{Cu}$ arsenates are a minor fraction and the signal of iron arsenates is very strong, their presence could be undercovered.

\section{Conclusions and Implications}

Our results revealed that As is present at higher concentrations in mine tailings (up to 12,672 \pm 34 $\mathrm{mg} \cdot \mathrm{kg}^{-1}$ ) and that there is an evidence of As spreading into the surrounding soils and plants with As content up to $326 \pm 10$ and $44 \pm 6 \mathrm{mg} \cdot \mathrm{kg}^{-1}$ respectively, and also spreading into a nearby creek was detected with concentrations up to $163 \pm 15 \mu \mathrm{g} \cdot \mathrm{L}^{-1}$. However, there is indication of natural attenuation, because the As concentrations in nearby soils and plant tissues are relatively low (2.6 
and $0.4 \%$ ), as compared to the high As content in mine tailings. As is present as $\mathrm{As}^{\mathrm{v}}$ forming hydrated iron arsenates such as kankite and, to a lesser extent, such as Asv sorbed into Fe-Ox. The presence of minerals such as kankite and beudantite was confirmed by EXAFS, $\mu$-XRF, and $\mu$ XAS. Iron arsenates such as kankite showed to be resistant to weathering, as demonstrated by combined SEP-XANES. In general, all of the results obtained have demonstrated the relatively low mobility of As; however, As susceptibility to mobilization remains a risk to the environment and to humans. As concentrations in collected soil and mine tailing samples surpassed the levels established in the Mexican regulation for total As content in soils for agricultural, commercial or residential, and industrial use. Arsenic detected in water samples from the creek also surpassed the EPA limit for human consumption. Phytoaccessible As exhibited values considered as phytotoxic, and also, data from As bioaccessibility revealed an Exposure Dose (ED) that represents a risk under a chronic-exposure scenario.

\section{Acknowledgments}

The authors wish to acknowledge to the National Council of Science and Technology (CONACyT; 328291), the International Atomic Energy Agency (17114), the International Centre for Theoretical Physics, Sandwich Training Educational Programme (MEX14029), the Thematic Network of Synchrotron Light Users (253719), the support of the agreement CONACyT and the LETRA Laboratory (255270), and the light sources where the work was performed; We acknowledge the Elettra Sincrotrone Trieste Facility for providing beam time (experiments 20120039 and 20125109) at the XAFS beamline and The Advanced Light Source is supported by the Director, Office of Science, Office of Basic Energy Sciences, of the U.S. Department of Energy under Contract no. DE-AC02-05CH11231.

Table 1. Low molecular weight organic acids (LMWOA) solution composition

\begin{tabular}{ccccc} 
Acid & {$[\mathbf{m M}]$} & Acid & {$[\mathbf{m M}]$} \\
\hline acetic & 2,898 & & tartaric & 26.3 \\
succinic & 194 & & fumaric & 12 \\
oxalic & 43 & citric & 6 \\
malic & 38.9 & & \\
\cline { 4 - 5 } & & &
\end{tabular}


Table 2. Arsenic (As) Exposure Dose (ED) in $\mathrm{mg} \cdot \mathrm{kg} \cdot \mathrm{day}^{-1}$, total content, bioaccessible and phytoaccessible in $\mathrm{mg} \cdot \mathrm{kg}^{-1}$ in samples of Tailings $(\mathrm{T})$ and Soils $(\mathrm{S})$ at $0.01 \mathrm{~m}(\mathrm{~s})$ and $0.3 \mathrm{~m}$ depth composites (c), Particle size (Ps), <0.25 (mesh 60) and <0.85 mm (mesh 20)

\begin{tabular}{|c|c|c|c|c|c|c|c|}
\hline Ps & Sample & $\begin{array}{l}\text { Total As } \\
\text { (GH-AAS) }\end{array}$ & $\begin{array}{l}\text { Total As } \\
\text { (XRF) }\end{array}$ & $\begin{array}{l}\text { Total As } \\
\text { (ICP-OES) }\end{array}$ & $\begin{array}{l}\text { As Bio- } \\
\text { accesible }^{a}\end{array}$ & $\mathbf{E D}^{\mathrm{a}}$ & $\begin{array}{l}\text { As Phyto- } \\
\text { accesible }\end{array}$ \\
\hline \multirow{14}{*}{$<0.25 \mathrm{~mm}$} & T1s & $12485 \pm 400$ & $6350 \pm 368$ & $8633 \pm 139$ & $389 \pm 10$ & $5.90 \mathrm{E}-04$ & $591 \pm 104$ \\
\hline & T1c & $11709 \pm 350$ & $5780 \pm 1336$ & $7610 \pm 698$ & $266 \pm 10$ & $4.00 \mathrm{E}-04$ & $409 \pm 20$ \\
\hline & $\mathrm{T} 2 \mathrm{~s}$ & $3139 \pm 300$ & $4650 \pm 270$ & $6993 \pm 151$ & $689 \pm 16$ & $1.00 \mathrm{E}-03$ & $447 \pm 100$ \\
\hline & T2c & $4776 \pm 210$ & $6010 \pm 351$ & $8144 \pm 62$ & $369 \pm 65$ & $5.60 \mathrm{E}-04$ & $429 \pm 25$ \\
\hline & T3s & $12672 \pm 34$ & I & I & $583 \pm 77$ & $8.90 \mathrm{E}-04$ & $677 \pm 198$ \\
\hline & T3c & $11939 \pm 35$ & I & I & $479 \pm 66$ & 7.30E-04 & $439 \pm 74$ \\
\hline & $\mathrm{T} 4 \mathrm{~s}$ & $9020 \pm 130$ & I & I & $351 \pm 30$ & $5.30 \mathrm{E}-04$ & $392 \pm 30$ \\
\hline & T4c & $6342 \pm 273$ & I & I & $522 \pm 128$ & $7.90 \mathrm{E}-04$ & $363 \pm 185$ \\
\hline & S1c & $326 \pm 10$ & $245 \pm+32$ & $531 \pm 40$ & $63 \pm 20$ & $9.60 \mathrm{E}-05$ & $79 \pm 10$ \\
\hline & S2c & $435 \pm 21$ & I & I & $177 \pm 13$ & $2.70 \mathrm{E}-04$ & $71 \pm 10$ \\
\hline & S3c & $538 \pm 10$ & I & I & I & I & 1 \\
\hline & S4c & $552 \pm 13$ & I & I & I & I & I \\
\hline & S5c & $685 \pm 10$ & I & I & I & I & I \\
\hline & S6c & $260 \pm 11$ & I & I & $67 \pm 10$ & $1.00 \mathrm{E}-04$ & $43 \pm 10$ \\
\hline \multirow{14}{*}{$<0.85 \mathrm{~mm}$} & T1s & $12469 \pm 20$ & $4860 \pm 285$ & $6648 \pm 479$ & & & $476 \pm 23$ \\
\hline & T1c & $10471 \pm 788$ & $4930 \pm 290$ & $7566 \pm 698$ & & & $714 \pm 77$ \\
\hline & $\mathrm{T} 2 \mathrm{~s}$ & $3294 \pm 413$ & $5060 \pm 30$ & $7973 \pm 108$ & & & $457 \pm 31$ \\
\hline & T2c & $5145 \pm 60$ & $4160 \pm 245$ & $5736 \pm 392$ & & & $211 \pm 11$ \\
\hline & T3s & $11902 \pm 65$ & I & I & & & $388 \pm 36$ \\
\hline & T3c & $11323 \pm 100$ & I & I & & & $406 \pm 16$ \\
\hline & T4s & $7917 \pm 148$ & I & I & & & $334 \pm 11$ \\
\hline & T4c & $5789 \pm 560$ & I & I & & & $249 \pm 10$ \\
\hline & S1c & $209 \pm 10$ & $365 \pm 37$ & $362 \pm 43$ & & & $71.4 \pm 10$ \\
\hline & S2c & $383 \pm 17$ & I & I & & & $116 \pm 32$ \\
\hline & S3c & $719 \pm 13$ & I & I & & & 1 \\
\hline & S4c & $181 \pm 17$ & I & I & & & I \\
\hline & S5c & $447 \pm 75$ & I & I & & & I \\
\hline & S6c & $226 \pm 10$ & I & / & & & $62 \pm 34$ \\
\hline
\end{tabular}

${ }^{a}$ Bioaccessibility and Exposure Dose (ED) applies only to the $<0.25 \mathrm{~mm}$ Particle size (Ps) in the samples; (/) not performed. 
Table 3. Arsenic content in roots, stems, and leaves in $\mathrm{mg} \cdot \mathrm{kg}^{-1}$ and As Bioaccumulation (BF) and Translocation Factors (TF) in plant species collected at the mine tailings sampling zone.

\begin{tabular}{cccccc} 
Plant & Root & Stem & Leaves & BF & TF \\
\hline Fouquieria splendens & $27 \pm 6$ & $15 \pm 4$ & $7 \pm 2$ & 0.23 & 0.26 \\
Cineraria marítima & $36 \pm 4$ & $22 \pm 4$ & $23 \pm 4$ & 0.32 & 0.61 \\
Baccharisicifolia & $44 \pm 6$ & $30 \pm 4$ & $6 \pm 2$ & 0.38 & 0.14 \\
Acacia farnesiana & $6 \pm 2$ & <D. L. & $<$ D. L & $/$ & $/$ \\
Clinopodium chilensis & $6 \pm 2$ & <D. L. & $6 \pm 2$ & $/$ & $/$ \\
Opuntia subulata & <D. L. & <D. L. & <D. L. & $/$ & $/$ \\
\hline \multicolumn{5}{c}{ <D.L. = below Detection Limit; / = not performed }
\end{tabular}

Table 4. Arsenic fractionation using a Sequential Extraction Procedure (SEP) in samples of Tailings (T) and Soils (S) at $0.01 \mathrm{~m}(\mathrm{~s})$ and $0.3 \mathrm{~m}$ depth composite (c) or reference (r), particle size $<0.25$ (mesh 60) and $<0.85 \mathrm{~mm}$ (mesh 20)

\begin{tabular}{ccccccccccc} 
& \multicolumn{2}{c}{ Exchangeable } & \multicolumn{2}{c}{ Adsorbed } & Amorphous Fe-Ox & Crystalline Fe-Ox & \multicolumn{2}{c}{ Residual } \\
\cline { 2 - 10 } R.Size & $<0.25$ & $<0.85$ & $<0.25$ & $<0.85$ & $<0.25$ & $<0.85$ & $<0.25$ & $<0.85$ & $<0.25$ & $<0.85$ \\
$\begin{array}{r}\text { Sample } \\
\text { T1s }\end{array}$ & $70 \pm 14$ & $119 \pm 10$ & $<$ D.L. & $<$ D.L. & $18 \pm 10$ & $12 \pm 5$ & $4,117 \pm 174$ & $2,244 \pm 159$ & $512 \pm 10$ & $460 \pm 10$ \\
T1c & $415 \pm 11$ & $178 \pm 20$ & $<$ D.L. & $<$ D.L. & $10 \pm 5$ & $10 \pm 5$ & $3,751 \pm 100$ & $2,474 \pm 146$ & $826 \pm 10$ & $730 \pm 20$ \\
T2s & $93 \pm 20$ & $114 \pm 40$ & $<$ D.L. & $<$ D.L. & $8 \pm 5$ & $14 \pm 5$ & $1,317 \pm 290$ & $1,491 \pm 305$ & $377 \pm 6$ & $276 \pm 10$ \\
T2c & $192 \pm 32$ & $29 \pm 11$ & $<$ D.L. & $<$ D.L. & $<$ D.L. & $<$ D.L. & $4,034 \pm 732$ & $3,084 \pm 288$ & $398 \pm 8$ & $412 \pm 10$ \\
T3s & $133 \pm 5$ & $141 \pm 47$ & $49 \pm 11$ & $44 \pm 5$ & $95 \pm 5$ & $104 \pm 10$ & $3,677 \pm 251$ & $3,418 \pm 86$ & $571 \pm 100$ & $381 \pm 14$ \\
T3c & $113 \pm 10$ & $100 \pm 6$ & $102 \pm 29$ & $92 \pm 5$ & $79 \pm 27$ & $93 \pm 5$ & $4,551 \pm 452$ & $4,459 \pm 100$ & $733 \pm 49$ & $663 \pm 44$ \\
T4s & $193 \pm 10$ & $177 \pm 26$ & $81 \pm 5$ & $100 \pm 20$ & $97 \pm 14$ & $99 \pm 5$ & $5,233 \pm 441$ & $4,805 \pm 419$ & $925 \pm 35$ & $494 \pm 8$ \\
T4c & $73 \pm 10$ & $53 \pm 8$ & $131 \pm 10$ & $106 \pm 19$ & $106 \pm 5$ & $102 \pm 5$ & $4,736 \pm 269$ & $3,604 \pm 855$ & $616 \pm 68$ & $648 \pm 31$ \\
S1c & $<$ D.L. & $<$ D.L. & $<$ D.L. & $<$ D.L. & $<$ D.L. & $10 \pm 5$ & $236 \pm 50$ & $81 \pm 10$ & $<$ D.L. & $<$ D.L. \\
S2c & $42 \pm 5$ & $29 \pm 11$ & $23 \pm 5$ & $36 \pm 10$ & $8 \pm 5$ & $7 \pm 5$ & $354 \pm 8$ & $83 \pm 27$ & $35 \pm 8$ & $33 \pm 8$ \\
S1r & $40 \pm 5$ & $24 \pm 8$ & $16 \pm 5$ & $13 \pm 5$ & $<$ D.L. & $<$ D.L. & $80 \pm 23$ & $80 \pm 23$ & $44 \pm 6$ & $30 \pm 10$
\end{tabular}


Table 5. XANES LCA of some representative samples of Tailings (T) and Soils (S) at $0.01 \mathrm{~m}(\mathrm{~s})$ and $0.3 \mathrm{~m}$ depth composite (c), particle size $<0.25$ (mesh 60) and $<0.85 \mathrm{~mm}$ (mesh 20)

\begin{tabular}{ccccccc} 
P size & Sample & Kankite $^{\mathrm{a}}$ & Beudantite $^{\mathrm{b}}$ & Bukosvkyite $^{\mathbf{c}}$ & Clinoclase $^{\mathrm{d}}$ & R-factor \\
\hline \multirow{4}{*}{$<0.25 \mathrm{~mm}$} & T1s & 0.55 & 0.31 & 0.13 & 0.00 & 0.0028 \\
& T1c & 0.51 & 0.48 & 0.01 & 0.01 & 0.0036 \\
& T2s & 0.34 & 0.34 & 0.00 & 0.32 & 0.0110 \\
& T2c & 0.41 & 0.42 & 0.00 & 0.18 & 0.0060 \\
& S1c & 0.51 & 0.18 & 0.24 & 0.07 & 0.0004 \\
$<0.85 \mathrm{~mm}$ & T1s & 0.35 & 0.39 & 0.00 & 0.27 & 0.0086 \\
& T1c & 0.25 & 0.28 & 0.46 & 0.01 & 0.0016 \\
& T2s & 0.32 & 0.15 & 0.50 & 0.03 & 0.0015 \\
& T2c & 0.29 & 0.50 & 0.00 & 0.22 & 0.0059 \\
\hline Standards: ${ }^{\mathrm{a}}\left(\mathrm{FeAsO}_{4} \cdot 3.5 \mathrm{H}_{2} \mathrm{O}\right) ;{ }^{b}\left(\mathrm{PbFe}_{3}\left(\mathrm{AsO}_{4}\right)\left(\mathrm{SO}_{4}\right)(\mathrm{OH})_{6}\right) ;{ }^{\mathrm{c}}\left(\mathrm{Fe}_{2}\left(\mathrm{AsO}_{4}\right)\left(\mathrm{SO}_{4}\right)(\mathrm{OH}) \cdot 7 \mathrm{H}_{2} \mathrm{O}\right) ;{ }^{\mathrm{d}}\left(\mathrm{Cu}_{3} \mathrm{AsO}_{4}(\mathrm{OH})_{3}\right)$.
\end{tabular}

Table 6. EXAFS fit results from a representative sample of Tailings (T) and Soils (S) $0.3 \mathrm{~m}$ depth composites (c), particle size $<0.25$ (mesh 60) scorodite and kankite standard using the refined scorodite theoretical signal.

\begin{tabular}{cccccc} 
& Atom & N & R (nm) & SS & R-factor \\
\hline Scorodite & $\mathrm{O}$ & 4 & 0.168 & 0.00209 & 0.0345 \\
& $\mathrm{O}$ & 12 & 0.305 & 0.02257 & \\
& $\mathrm{Fe}$ & 3 & 0.334 & 0.00949 & \\
\hline \multirow{3}{*}{ Kankite } & $\mathrm{O}$ & 4 & 0.169 & 0.0010 & 0.0188 \\
& $\mathrm{O}$ & 12 & 0.323 & 0.0090 & \\
& $\mathrm{Fe}$ & 3 & 0.331 & 0.0075 & \\
\multirow{2}{*}{$\mathrm{Tc}$} & $\mathrm{O}$ & 4 & 0.169 & 0.0014 & 0.0201 \\
& $\mathrm{O}$ & 12 & 0.320 & 0.0047 & \\
\hline \multirow{3}{*}{$\mathrm{Sc}$} & $\mathrm{Fe}$ & 3 & 0.332 & 0.0070 & \\
& $\mathrm{O}$ & 4 & 0.169 & 0.0002 & 0.0170 \\
& $\mathrm{O}$ & 12 & 0.320 & 0.0112 & \\
\hline
\end{tabular}

$N=$ degeneracy Number; $\mathrm{R}=$ Radial distance; $\mathrm{SS}=$ Sigma Square. 


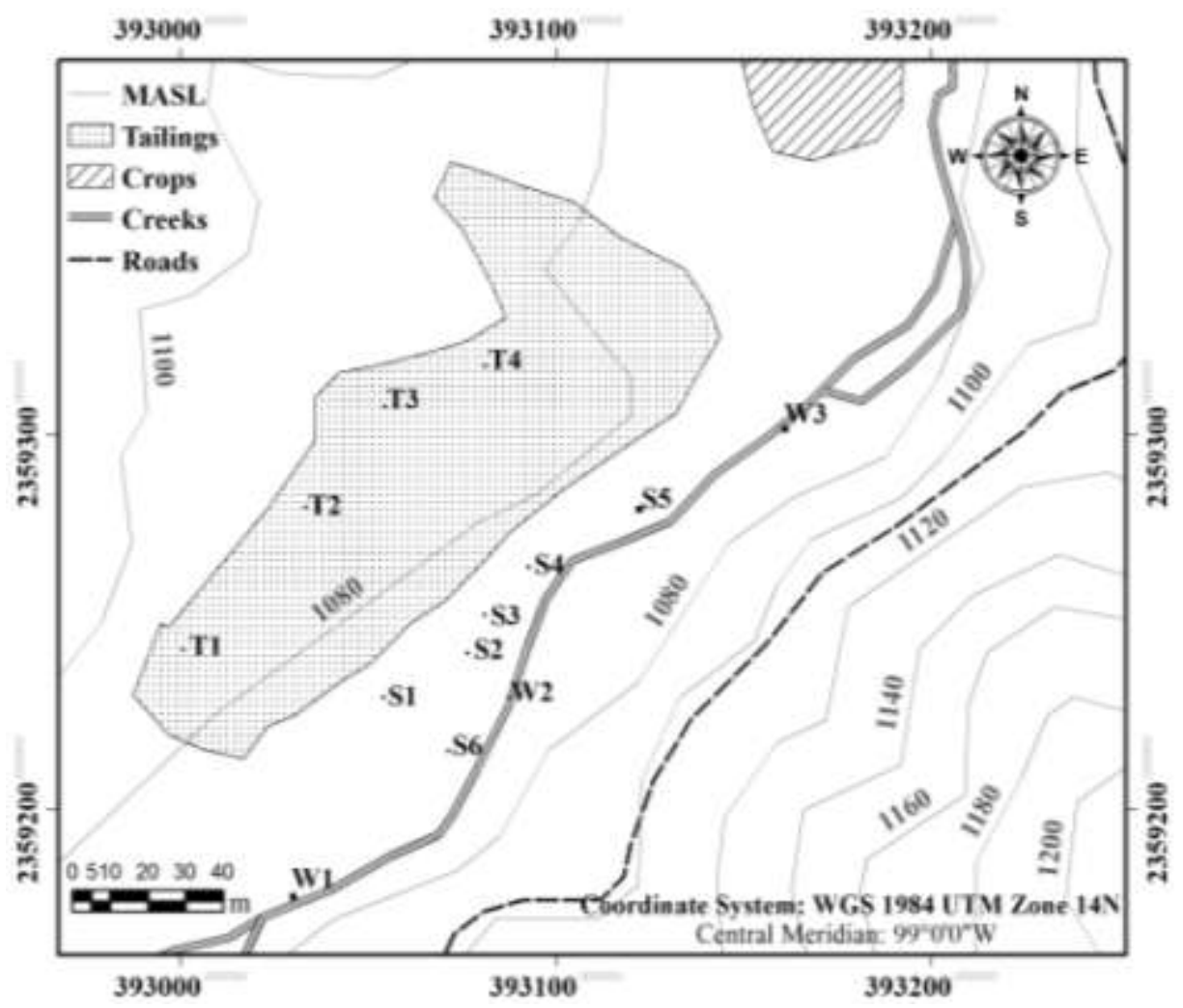

Fig. 1. Map of mine tailings sampling zone at the "La Aurora" mining site in Xichú, Guanajuato, Mexico. Sampling points of Tailings (T), Soils (S), and Water (W) are depicted
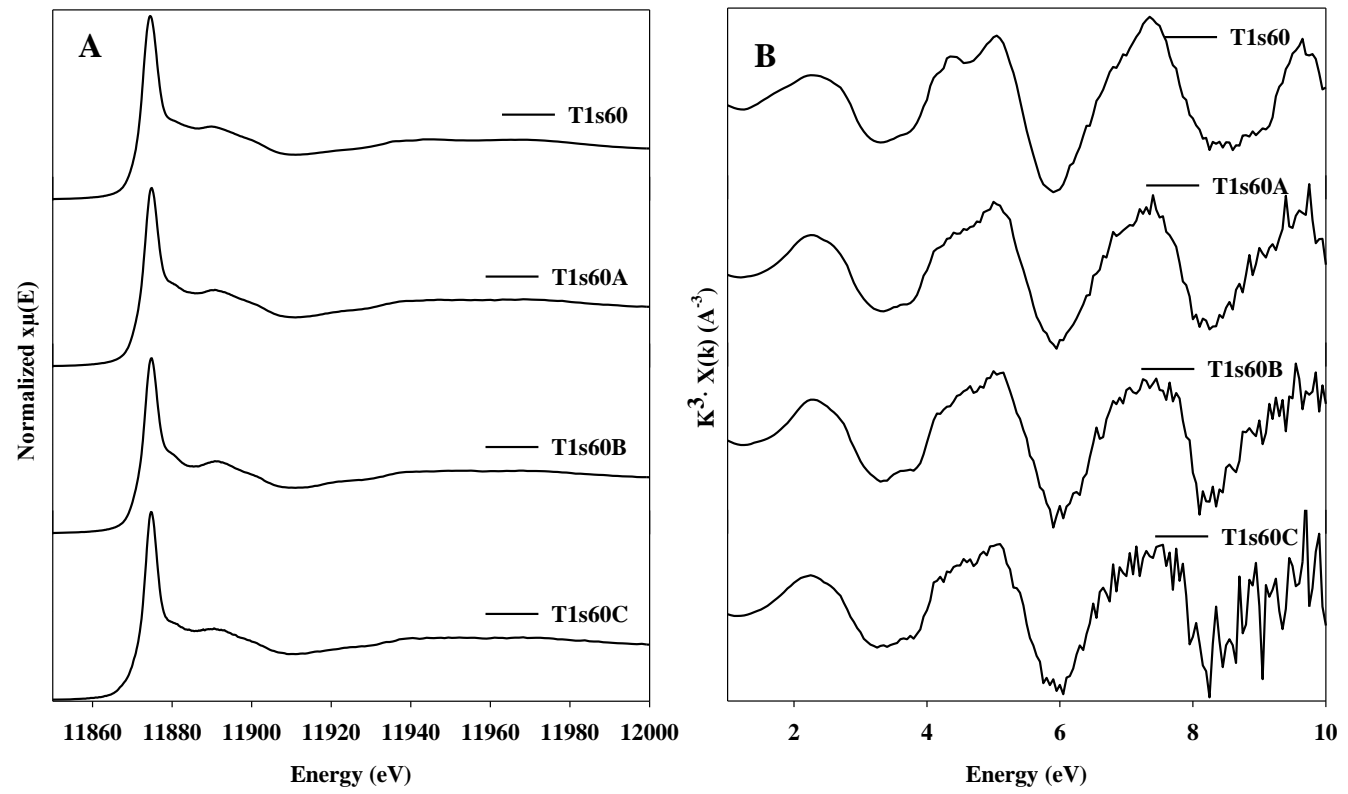

Fig. 3. As XANES spectra in the energy (A) and k space (B) of one mine Tailing (T) $0.01 \mathrm{~m}$ in depth (s) and particle size $<0.25 \mathrm{~mm}$ (mesh 60) and its residues from SEP, A) Containing As associated to amorphous and crystalline iron oxides and residual As fractions; B) containing As associated to crystalline iron oxides and residual As fractions, and C) containing only As residual fraction. 

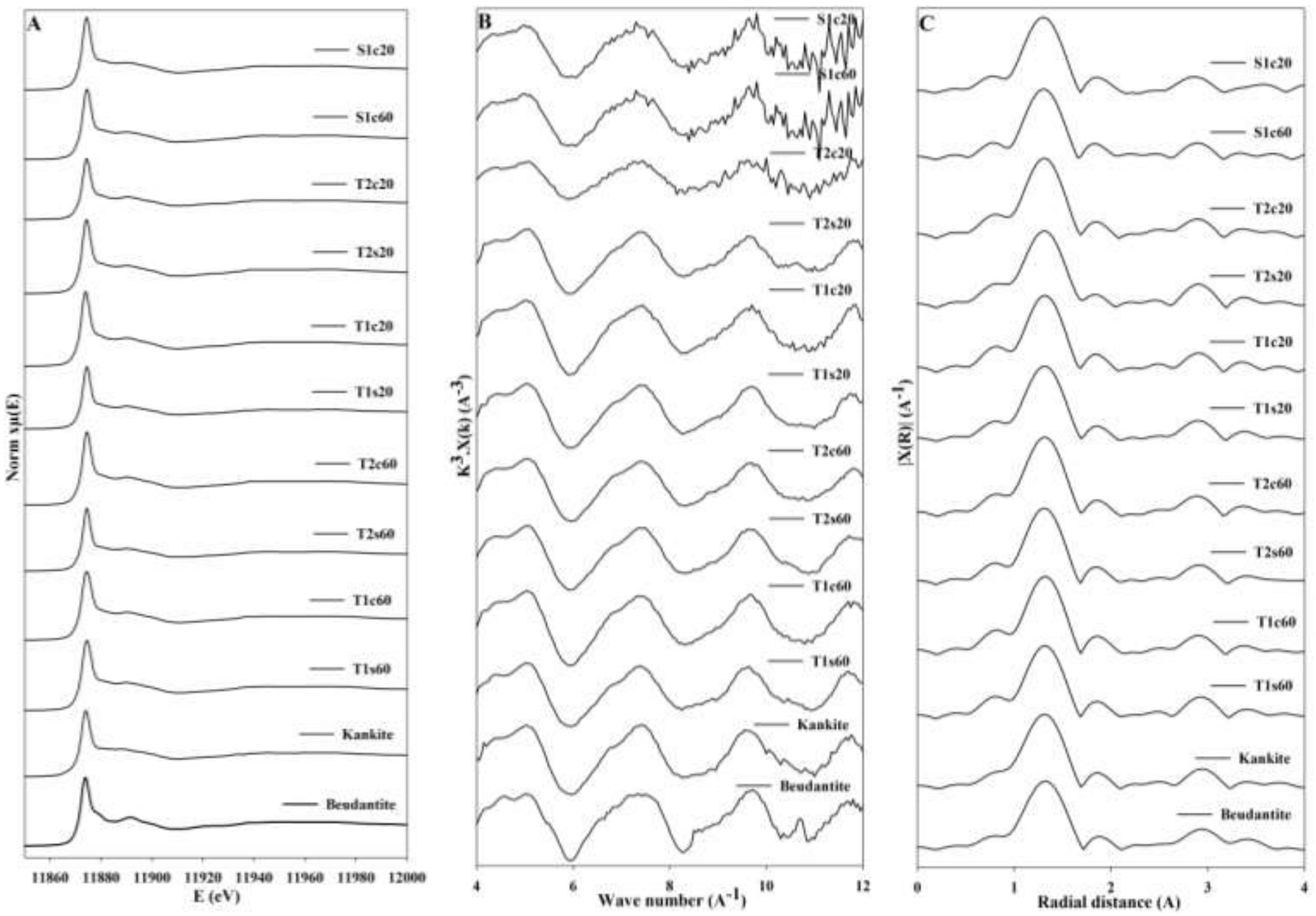

Fig. 2. XANES spectra in energy (A), k (B), and R (C) space of samples of Tailings (T) and Soils (S) at $0.01 \mathrm{~m}(\mathrm{~s})$ and $0.3 \mathrm{~m}$ depth composite (c), particle size $<0.25$ (mesh 60) and $<0.85 \mathrm{~mm}$ (mesh 20) 

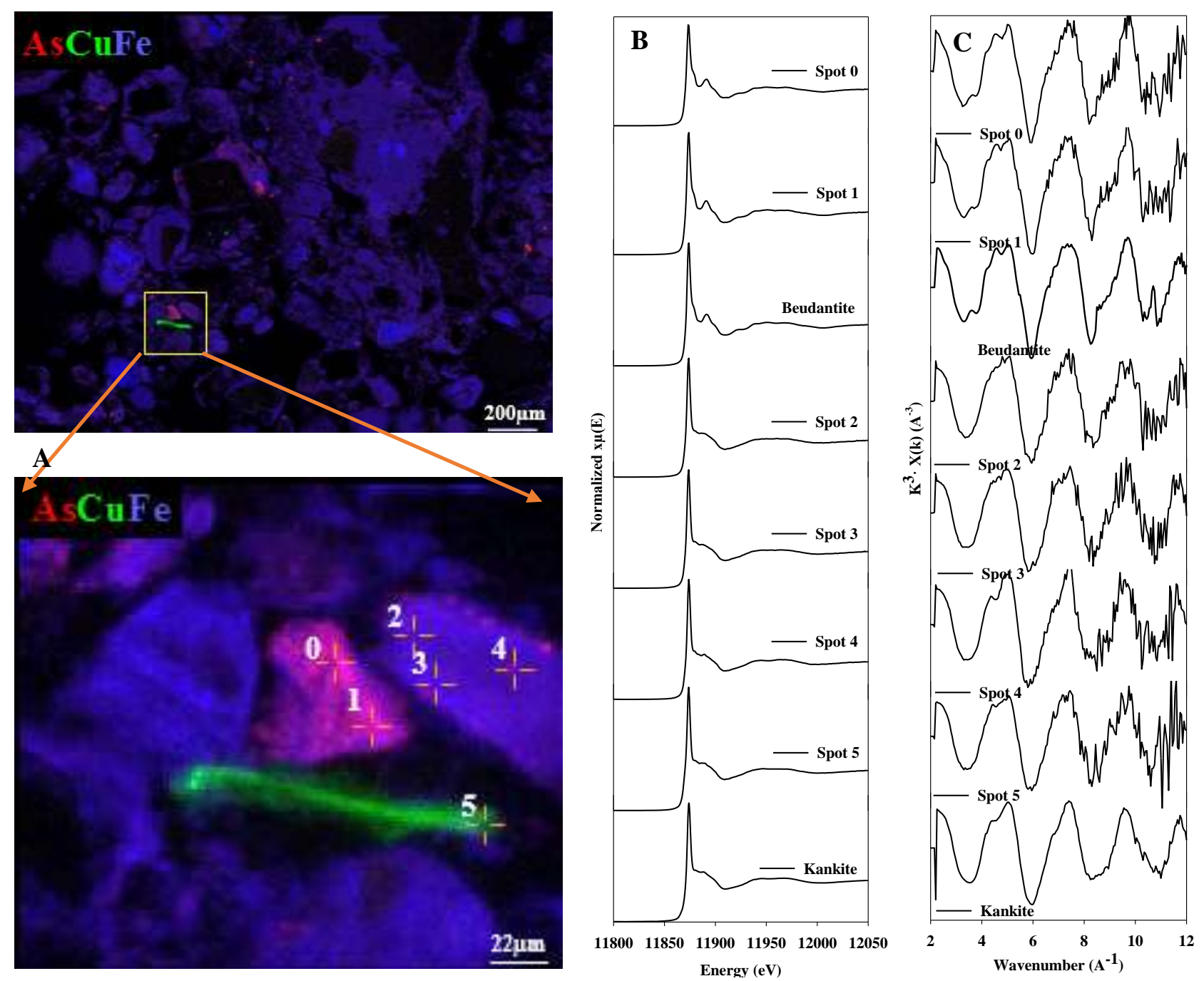

Fig. 4. $\mu$-XRF maps from zone 1 (A) and from a Tailing (T) sample, particle size $<0.25 \mathrm{~mm}$ (mesh 60 ), and -XANES in energy $(\mathrm{B})$ and $\mathrm{k}$ space $(\mathrm{C})$ marked spots and mineral standards kankite $\left(\mathrm{FeAsO}_{4} \cdot 5 \mathrm{H}_{2} \mathrm{O}\right)$ and beudantite $\left(\mathrm{PbFe}_{3}\left(\mathrm{AsO}_{4}\right)\left(\mathrm{SO}_{4}\right)(\mathrm{OH})_{6}\right)$ of marked spots in $\mathrm{A}$ 

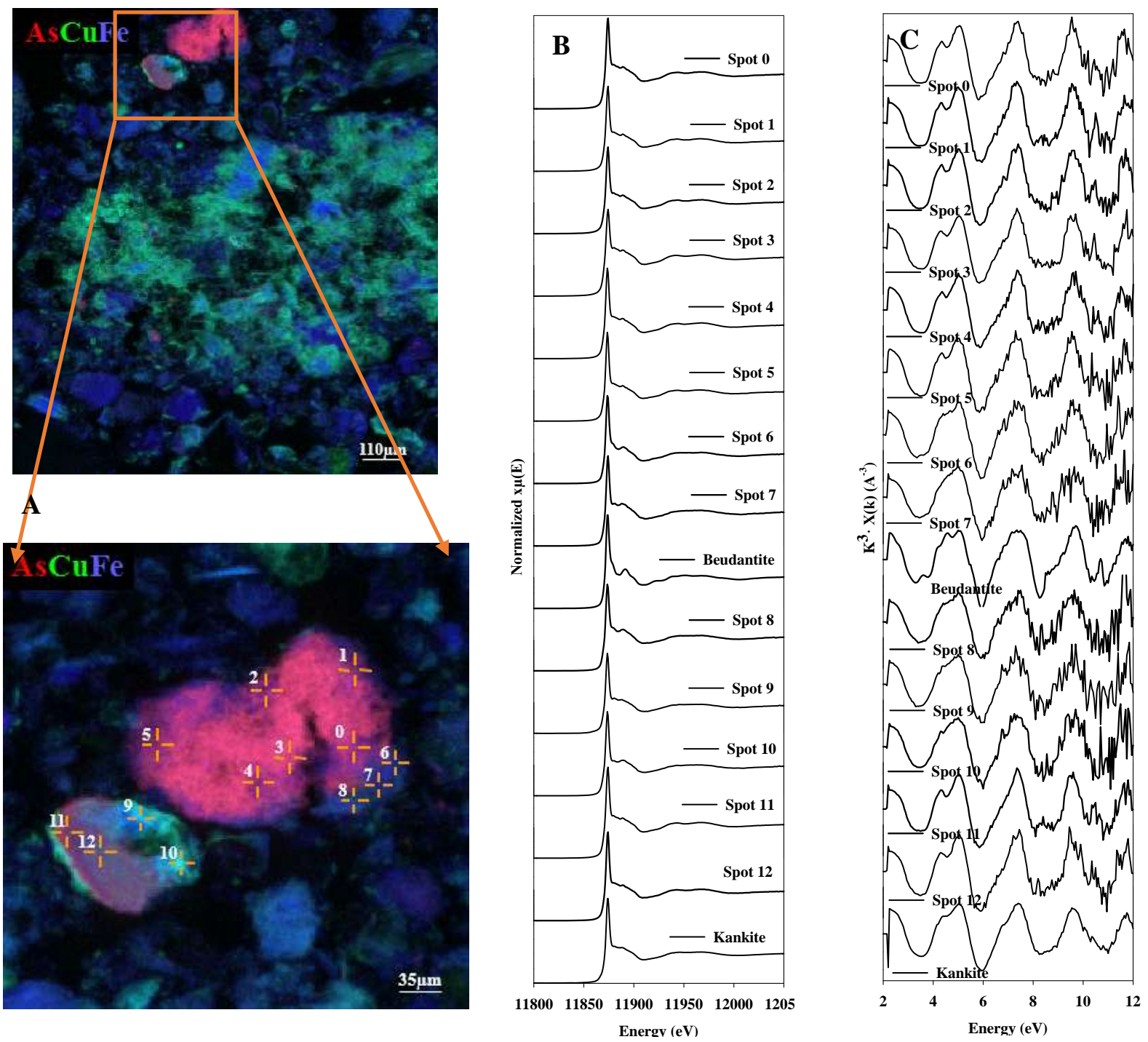

Fig. 5. $\mu \mathrm{XRF}$ maps from zone 2 (A) and from a tailing sample particle size of $<0.25 \mathrm{~mm}$ (mesh 60 ), and $\mu$-XANES in energy (B) and $\mathrm{k}$ space (C) marked spots and mineral standards of kankite $\left(\mathrm{FeAsO}_{4} \cdot 5 \mathrm{H}_{2} \mathrm{O}\right)$ and beudantite $\left(\mathrm{PbFe}_{3}\left(\mathrm{AsO}_{4}\right)\left(\mathrm{SO}_{4}\right)(\mathrm{OH})_{6}\right)$ of marked spots on $\mathrm{A}$.

\section{References}

1. Diario-Oficial, Decreto por el cual se declara área natural protegida, con el carácter de reserva de la biosfera, a la zona conocida como Sierra Gorda de Guanajuato localizada en los municipios de Atarjea, San Luis de la Paz, Santa Catarina, Victoria y Xichú, en el Estado de Guanajuato, S.d.M.A.y.R. Naturales, Editor. 2007. p. 22.[In Spanish]

2. SGM., Panorama Minero del Estado de Guanajuato, in Panorama minero de los estados, Sistema Geológico Mexicano, Editor. 2014, Secretaria de Gestión y Medio Ambiente: Mexico. p. 53.[In Spanish] 
3. Carrillo-Chávez, A., et al., Geochemistry and mineralogy of mine-waste material from a "skarn-type" deposit in central Mexico: Modeling geochemical controls of metals in the surface environment. Journal of Geochemical Exploration, 2014. 144, Part A: p. 28 - 36.

4. Miranda Gasca, M.A., Estudio geológico-geoquímico regional del área de Xichú, estado de Guanajuato. Boletín de la Sociedad Geológica Méxicana, 1978. 39(2): p. 101-106.[In Spanish]

5. Ayala de la Portilla, H.E., et al. Determinación de la bioacumulación de metales pesados en plantas del borde de un arroyo en una zona minera. in 2nd Mexico Young Water Professional Conference. 2010. [in Spanish]

6. HSS, Toxicological profile for arsenic, in Toxicological profile Information, Agency for Toxic Substances and Disease Registry, Editor.2007. p. 559.

7. Manning, B., Arsenic speciation in As(III)- and As(V)-treated soil using XANES spectroscopy. Microchimica Acta, 2005. 151(3): p. 181-188.

8. Roussel, C., Hubert B., and Fernandez, A., Arsenic speciation: involvement in evaluation of environmental impact caused by mine wastes. Journal of environmental quality, 2000. 29(1): p. 182-188.

9. Ahn, J.S., et al., Mineralogical and geochemical characterization of arsenic in an abandoned mine tailings of Korea. Environmental Geochemistry and Health, 2005. 27(2): p. $147-57$.

10. Peijnenburg, W.J. and Jager, T., Monitoring approaches to assess bioaccessibility and bioavailability of metals: matrix issues. Ecotoxicology and Environmental Safety, 2003. 56(1): p. 63-77.

11. Krishnamurti, G.S.R. and Naidu, R., Solid-solution speciation and phytoavailability of copper and zinc in soils. Environmental Science \& Technology, 2002. 36(12): p. 2645-51.

12. Krishnamurti, G.S.R., et al., Solid-phase speciation and phytoavailability of copper in representative soils of Italy. Chemical Speciation \& Bioavailability, 2007. 19(2): p. 57-67.

13. Huang, P.M. and Gobran, C.R., Biogeochemistry of Trace Elements in the Rhizosphere, Amsterdam: Elsevier B. V. 2005. p. 480.

14. Hodson, M.E., Vijver, M.G. and Peijnenber, W.J.G.M., Bioavailability in soils, in Dealing with contaminated sites, F.A. Swartjes, Editor. 2011, Springer Netherlands. p. 721-746.

15. Dean, J.R., Bioavailability, Bioaccessibility and Mobility of Environmental Contaminants. Analytical Techniques in the Sciences. 2007, England: Jhon Wiley \& Sons, Ltd. p. 316.

16. Juhasz, A.L., Weber, J. and Smith, E., Impact of soil particle size and bioaccessibility on children and adult lead exposure in peri-urban contaminated soils. Journal of Hazardous Materials, 2011. 186(2-3): p. 1870-1879. 
17. Jelusic, M., et al., Effect of EDTA washing of metal polluted garden soils. Part II: Can remediated soil be used as a plant substrate? in Science of The Total Environment. 2014. Elsevier B. V. 475: p. 142-152.

18. Souissi, R., et al., Study of contaminanted soils of the abandoned $\mathrm{Pb}, \mathrm{Zn}, \mathrm{Cd}$ Jebel Ressas mine tailings (Norht eastern Tunisia), in EGU General Assembly. 2012. Vienna, Austria: Geophysical Research Abstracts. p. 1.

19. Tessier, A., Campbell, P.G.C. and Bisson, M., Sequential extraction procedure for the speciation of particulate trace metals. Analytical Chemistry, 1979. 51(7): p. 844-851.

20. Bakircioglu, D., Bakircioglu, K.Y., and Ibar, H., Comparison of extraction procedures for assesing soil metal bioavailability of to weath grains. Clean Soil Air Water, 2011. 39(8): p. 728-734.

21. Sarret, G., et al., Use of Synchrotron-Based Techniques to Elucidate Metal Uptake and Metabolism in Plants, in Advances in Agronomy, D.L. Sparks, Editor. 2013, Elsevier B. V.: USA. p. 1-82.

22. Luo, L. and Zhang, S., Applications of synchrotron-based X-ray Techniques in environmental science. Science China Chemistry, 2010. 53(12): p. 2529-2538.

23. Gerlach, R.W. and Nocerino, J.M., Guidance for obtaining representative laboratory analytical subsamples from particulate laboratory samples, United States Environmental Protection Agency, Editor. 2003, EPA: USA. p. 156.

24. SEMARNAT, Norma Oficial Mexicana, que establece criterios para determinar las concentraciones de remediación de suelos contaminados por arsénico, bario, berilio, cadmio, cromo, hexavalente, mercurio, níquel, plata, plomo, selenio, talio y/o vanadio. 2007, Diario Oficial: Mexico. p. 69. [In Spanish].

25. USEPA, Method 3050B: Acid digestion of sediments, sludges and soils, Revsion 2, EPA, Editor. 1996: USA. p. 12.

26. Mejía, J., Carrizales, L., and Díaz-Barriga, F., Anexo 4. Evaluación de la exposición en sitios peligrosos. Zona minera de Villa de la Paz-Matehuala, in Metodología de identificación y evaluación de riesgos para la salud en sitios contaminados, CEPIS, Editor. 1998, OPS: Lima, Perú. p. 11. [In Spanish].

27. Cieśliński, G., et al., Low-molecular-weight organic acids in rhizosphere soils of durum wheat. Plant and Soils, 1998. 203(1): p. 109-117.

28. Rezvani, M. and Zaefarian, F., Bioaccumulation and translocation factors of cadmium and lead in Aeluropus littoralis. Australian Journal of Agricultural Engineering, 2011. 2(4): p. 114-119.

29. Wenzel, W.W., et al., Arsenic fractionation in soils using an improved sequential extraction procedure. Analytica Chimica Acta, 2001. 436(2): p. 309-323.

30. Di Cicco, A., et al., Novel XAFS capabilities at Elettra synchrotron light source. Journal of Physics: Conference Series, 2009. 190(1): p. 1-6. 
31. Niazi, N.K., Singh, B., and Shah., Arsenic speciation and phytoavailability in contaminated soils using a sequential extraction procedure and XANES spectroscopy. Environmental Science \& Technology, 2011. 45: p. 7135-7142.

32. Ravel, B. and Newville, M., Athena, Artemis, Hephaestus: data analysis for X-ray absorption spectroscopy using IFEFFIT. Journal of synchrotron radiation, 2005. 12(4): p. 537541.

33. Marcus, M.A., et al., Beamline 10.3.2 at ALS: a hard X-ray microprobe for environmental and materials sciences. Journal of Synchrotron Radiation, 2004. 11(3): p. 239247.

34. Necemer, M., et al., Application of X-ray fluorescence analytical techniques in phytoremediation and plant biology studies. Spectrochimica Acta Part B, 2008. 63(11): p. 12401247.

35. Ongley, L.K., et al., Arsenic in the soils of Zimapán, Mexico. Environmental pollution, 2007. 145(3): p. 793-799.

36. Razo, I., et al., Arsenic and heavy metal pollution of soil, water and sediments in a semi- arid climate mining area in Mexico. Water Air and Soil Pollution, 2004. 152(1): p. 129152.

37. Wilkin, R.T., Metal attenuation processes at mining sites, Ground Water Issue, EPA, Editor.2007. USA: p. 13.

38. Shaibur, M.R. and Kawai, S., Arsenic toxicity in Akitakomachi rice in presence of Fe3+-EDTA. Bangladesh Journal of Agricultural Research, 2011. 36(4): p. 553-562.

39. Vithanage, M., et al., Arsenic uptake by plants and possible phytoremediation applications: a brief overview. Environmental chemistry Letters, 2012. 10(3): p. 217-224.

40. EPA., Arsenic in drinking-water: Background document for development of WHO Guidelines for Drinking-water Quality, World Health Organization, Editor. 2001. USA: p. 24.

41. García-Salgado, S., et al., Arsenic and heavy metal uptake and accumulation in native plant species from soils polluted by mining activities. Water, Air \& Soil Pollution, 2012. 223(2): p. 559-572.

42. Qing-En, X., et al., The Arsenic hyperaccumulator fern Pteris vittata L. Environmental Science \& Technology, 2009. 43(22): p. 8488-8495.

43. Téllez-Hernández, J.I., Estabilización por fosfato de plomo y cadmio contenidos en suelos de Villa de la Paz-Matehuala, S.L.P., in Programa Multidisciplinario de Posgrado en Ciencias Ambientales. Tesis de Maestría. 2009, Universidad Autónoma de San Luis Potosí: S.L.P. México. p. 150. [In Spanish].

44. Ravenscroft, P., Brammer, H., and Richards, K., Hydrogeochemistry of arsenic, in Arsenic Pollution: A global Synshtesis. 2009, Wiley-Blackwell: Oxford, UK. p. 25-114. 
45. Haffert, L., Craw, D., and Pope, J., Climatic and compositional controls on secondary arsenic mineral formation in high-arsenic mine wastes, South Island, New Zealand. New Zealand Journal of Geology and Geophysics, 2010. 53(2-3): p. 91-101.

46. Drahota, P. and Filippi, M., Secondary arsenic minerals in the environment: a review. Environment International, 2009. 35(8): p. 1243-1255.

47. Conesa, M.H., et al., Metal extractability in acidic and neutral mine tailings from the Cartagena-La Unión Mining District (SE Spain). Applied Geochemistry, 2008. 23(5): p. 1232 1240 .

48. Kitahama, K., R. Kiriyama, and B. Yoshihisa, Refinement of the crystal structure of scorodite. Acta crystallographica, 1975. 31: p. 322-324.

49. Loredo Portales, R., et al., Understanding Copper speciation and mobilization in soils and mine tailings from "Mineral La Aurora" in central Mexico: contributions from Synchrotron techniques. Boletín de la sociedad Geológica Mexicana, 2015. 67(3): p. 447-456. 